Article

\title{
In Vivo Antimalarial Activity of Leaf Extracts and a Major Compound Isolated from Ranunculus multifidus Forsk
}

\author{
Betelhem Sirak $^{1}$ (D), Lea Mann ${ }^{2}$, Adrian Richter ${ }^{2}$, Kaleab Asres ${ }^{3, *}$ and Peter Imming ${ }^{2, *}$ \\ 1 Department of Pharmacy, College of Medicine and Health Sciences, Arba Minch University, \\ Arba Minch P.O. Box 21, Ethiopia; betelhem.sirak@amu.edu.et \\ 2 Department of Pharmaceutical Chemistry, Faculty of Natural Sciences, Martin-Luther-Universitaet \\ Halle-Wittenberg, 3, 06120 Halle (Saale), Germany; lea.mann@pharmazie.uni-halle.de (L.M.); \\ adrian.richter@pharmazie.uni-halle.de (A.R.) \\ 3 Department of Pharmaceutical Chemistry and Pharmacognosy, School of Pharmacy, College of Health \\ Sciences, Addis Ababa University, Addis Ababa P.O. Box 1176, Ethiopia \\ * Correspondence: kaleab.asres@aau.edu.et (K.A.); peter.imming@pharmazie.uni-halle.de (P.I.); \\ Tel.: +251-911404249 (K.A.); +49-3455525175 (P.I.)
}

Citation: Sirak, B.; Mann, L.; Richter, A.; Asres, K.; Imming, P. In Vivo Antimalarial Activity of Leaf Extracts and a Major Compound Isolated from Ranunculus multifidus Forsk. Molecules 2021, 26, 6179. https://doi.org/ $10.3390 /$ molecules 26206179

Academic Editor: Valeria Patricia Sülsen

Received: 20 August 2021

Accepted: 8 October 2021

Published: 13 October 2021

Publisher's Note: MDPI stays neutral with regard to jurisdictional claims in published maps and institutional affiliations.

Copyright: (c) 2021 by the authors. Licensee MDPI, Basel, Switzerland. This article is an open access article distributed under the terms and conditions of the Creative Commons Attribution (CC BY) license (https:// creativecommons.org/licenses/by/ $4.0 /)$.

\begin{abstract}
The leaves of Ranunculus multifidus Forsk. are traditionally used for the treatment of malaria in several African countries. In the present study, 80\% methanol (RM-M) and hydrodistilled (RM-H) extracts of fresh leaves from $R$. multifidus and its major constituent anemonin were tested for their in vivo antimalarial activity against Plasmodium berghei in mice. Anemonin was also tested for its in vitro antimycobacterial activity against Mycobacterium smegmatis and M. abscessus in a microbroth dilution assay, and bacterial growth was analyzed by OD measurement. The isolation of anemonin from RM-H was carried out using preparative thin layer chromatography (PTLC). The chemical structures of anemonin and its hydrolysis product were elucidated using spectroscopic methods (HR-MS; 1D and 2D-NMR). Results of the study revealed that both RM-M and RM-H were active against $P$. berghei in mice, although the latter demonstrated superior activity $(p<0.001)$, as compared to the former. At a dose of $35.00 \mathrm{mg} / \mathrm{kg} /$ day, RM-H demonstrated a chemosuppression value of $70 \%$ in a 4-day suppressive test. In a 4-day suppressive, Rane's and prophylactic antimalarial tests, anemonin showed median effective doses $\left(E_{50} \mathrm{~s}\right)$ of $2.17,2.78$ and $2.70 \mu \mathrm{M}$, respectively. However, anemonin did not inhibit the growth of M. smegmatis and M. abscessus.
\end{abstract}

Keywords: Ranunculus multifidus; 4-day suppressive test; Rane's test; prophylactic test; anemonin

\section{Introduction}

Malaria is one of the most pressing public health issues in developing countries [1]. There were an estimated 229 million malaria cases in 87 malaria-endemic countries worldwide (as of 2019), in which $94 \%$ of the cases (215 million) occurred in the African region [1]. The emergence and swift spread of multi-drug resistant Plasmodium parasites, the development of insecticide-resistant mosquitos, and the absence of effective vaccines are some of the challenges in the process of controlling and eventually eradicating malaria [2,3]. In Ethiopia, malaria is one of the main public health and economic problems, with $75 \%$ of the landscape below $2000 \mathrm{~m}$ above sea level affected by the disease [4]. In recent years, Ethiopia achieved a reduction in their malaria mortality rate by more than $40 \%$ [1], yet the disease is still one of the leading causes of morbidity and mortality [5].

Ranunculus multifidus Forsk. is a perennial herb that grows in moist, open grassy meadows near rivers, streams, and lakes as well as on wet slopes and in open mountain forests and is mostly considered a weed [6]. In the Democratic Republic of Congo, the leaves of $R$. multifidus are used for the treatment of malaria [7] while in different parts of Ethiopia, they are used to treat leishmaniasis [8-10]. In South Africa, it is used to treat sexually transmitted diseases, tuberculosis, genital sores, warts, and hemorrhoids [11,12]. 
Most members of the genus Ranunculus biosynthesize the toxic glycoside ranunculin, which is then converted into protoanemonin via enzymatic hydrolysis. Protoanemonin will then cyclodimerize to yield the water-insoluble crystalline dimer anemonin [13]. A previous study demonstrated that the whole plant of $R$. multifidus extracted with dichloromethanemethanol (1:1), possesses in vitro antimalarial activity against a chloroquine-sensitive strain of Plasmodium falciparum with an $\mathrm{IC}_{50}$ value of $2.3 \mu \mathrm{g} / \mathrm{mL}$ [14]. The objective of this study was to investigate the in vivo antimalarial effect of extracts from the leaves of $R$. multifidus and its major constituent in mice infected with a chloroquine-sensitive strain of P. berghei.

\section{Results and Discussion}

\subsection{Acute Oral Toxicity}

The acute toxicity test results of the present study documented that the hydroalcoholic extract (RM-M) was safe by the oral route at a dose of $2000 \mathrm{mg} / \mathrm{kg}$ as no mortality or signs of toxicity were observed within 14 days, which suggests that the $50 \%$ lethal dose $\left(\mathrm{LD}_{50}\right)$ of RM-M is above $2000 \mathrm{mg} / \mathrm{kg}$. However, at the same dose, the hydrodistilled extract (RM-H) showed severe toxicity leading to death in experimental animals. The main test revealed that RM-H has an $\mathrm{LD}_{50}$ higher than $175 \mathrm{mg} / \mathrm{kg}$ but lower than $550 \mathrm{mg} / \mathrm{kg}$.

\subsection{Antimalarial Activity of Extracts}

In the current study, the in vivo antimalarial activity of $R$. multifidus leaf extracts was examined using the classic 4-day suppressive test to evaluate the chemosuppressive effect of the plant extract during early infection. The percent of the inhibition of parasitemia (percent of suppression) and the survival time were taken as parameters for the determination of activity of the test substances throughout the assay. Moreover, as malarial infection causes anemia, changes in body (rectal) temperature, and body weight loss, the potential of the tested substances to reduce anemia, prevent body weight loss, and regulate body temperature in the infected mice were also studied.

The experimental results showed that both RM-M and RM-H provide a chemosuppressive effect on parasitemia in a manner that is dose-independent. These effects were statistically significant relative to the negative control group $(p<0.001)$. The chemosuppression percentages ranged from $39.2 \%$ to $70.6 \%$. As shown in Table 1, RM-H exhibited a significant inhibition $(p<0.001)$ of parasite multiplication $(70.6 \%)$ at an oral dose of $35.00 \mathrm{mg} / \mathrm{kg}$ per day. All tested doses of the extracts exhibited significantly lower $(p<0.001)$ parasitemia reduction compared to the positive control group. Moreover, the test substances prolonged mean survival time (MST) significantly $(p<0.001)$, as compared to the negative control group; however, the values were significantly $(p<0.001)$ smaller than the standard drug chloroquine.

Table 1. Antimalarial activity of the leaf extracts of Ranunculus multifidus in mice infected with Plasmodium berghei in 4-day suppressive test.

\begin{tabular}{cccc}
\hline $\begin{array}{c}\text { Test Substances } \\
\text { (mg/kg/day) }\end{array}$ & \% Parasitemia & \% Suppression & $\begin{array}{c}\text { Mean Survival Time } \\
\text { (in Days) }\end{array}$ \\
\hline 2\% TW80 & $26.6 \pm 0.7$ & - & $9.1 \pm 0.3$ \\
CQ 25 & $0.2 \pm 0.2^{\mathrm{a} 3}$ & 99.2 & $28 \pm 0.0^{\mathrm{a} 2}$ \\
RM-M 100 & $15.8 \pm 1.0^{\mathrm{a} 2, \mathrm{~b} 2, \mathrm{c} 2, \mathrm{~d} 1, \mathrm{e} 2, \mathrm{f} 2, \mathrm{~g} 2}$ & 39.2 & $12.4 \pm 0.4^{\mathrm{a} 2, \mathrm{~b} 2, \mathrm{~g} 1}$ \\
RM-M 200 & $12.6 \pm 0.2^{\mathrm{a} 2, \mathrm{~b} 2, \mathrm{e} 2, \mathrm{f} 2, \mathrm{~g} 2}$ & 48.4 & $12.8 \pm 0.5^{\mathrm{a} 2, \mathrm{~b} 2, \mathrm{~g} 1}$ \\
RM-M 400 & $9.5 \pm 0.2^{\mathrm{a} 2, \mathrm{~b} 2, \mathrm{~g} 1, \mathrm{~g} 2}$ & 53.1 & $13.1 \pm 0.2^{\mathrm{a} 2, \mathrm{~b} 2}$ \\
RM-H 8.75 & $10.9 \pm 0.5^{\mathrm{a} 2, \mathrm{~b} 2, \mathrm{~g} 2}$ & 58.8 & $13.8 \pm 0.8^{\mathrm{a} 2, \mathrm{~b} 2}$ \\
RM-H 17.50 & $9.6 \pm 0.4^{\mathrm{a} 2, \mathrm{~b} 2, \mathrm{~g} 1}$ & 63.6 & $14.0 \pm 0.8^{\mathrm{a} 2, \mathrm{~b} 2}$ \\
RM-H 35.00 & $15.8 \pm 1.0^{\mathrm{a} 2, \mathrm{~b} 2,}$ & 70.6 & $14.4 \pm 0.5^{\mathrm{a} 2, \mathrm{~b} 2}$ \\
\hline
\end{tabular}

Data are expressed as mean \pm SEM; $n=5$; a: compared to $\%$ TW80 (Tween 80 ) vehicle, b: compared to chloroquine 25, c: compared to RM-M 200, d: compared to RM-M 400, e: compared to RM-H 8.75, f: compared to RM-H 17.50, g: compared to RM-H 35.00; 1: $p<0.05,2: p<0.001$; CQ: chloroquine phosphate, RM-M: 80\% methanol extract of R. multifidus, RM-H: hydrodistilled extract of $R$. multifidus. 
The 4-day suppressive test results demonstrated that the tested extracts prevent body weight reduction significantly $(p<0.001)$, as compared to the negative control group. While the effects of the lower $(100 \mathrm{mg} / \mathrm{kg} /$ day $)$ and middle $(200 \mathrm{mg} / \mathrm{kg} /$ day $)$ doses of RM-M were much less than that of the positive control group, the highest dose of RM-M and all dose levels of RM-H significantly $(p<0.001)$ protected parasite-induced weight reduction in infected mice, as compared to those in the negative control group (Table 2). All dose levels of the tested extracts significantly $(p<0.001)$ prevented a reduction in rectal temperature, as compared to the negative control group. As shown in Table 2, except for the lower (100 mg/kg/day) and middle (200 mg/kg/day) doses of RM-M, all others displayed statistically comparable temperature stabilization effects, as compared with that of the standard drug. All dose levels of RM-M and RM-H exhibited a statistically significant $(p<0.001)$ effect on the circumvention of packed-cell-volume (PCV) decline in $P$. berghei-infected mice, as compared to the negative control group, although their effect was lower $(p<0.001)$ than that of the standard drug.

Table 2. Effect of leaf extracts of Ranunculus multifidus on body weight, rectal temperature and packed cell volume of Plasmodium berghei-infected mice in 4-day suppressive test.

\begin{tabular}{|c|c|c|c|c|c|c|c|c|c|}
\hline \multirow{2}{*}{$\begin{array}{c}\text { Test } \\
\text { Substances } \\
\text { (mg/kg/day) }\end{array}$} & \multicolumn{3}{|c|}{ Body Weight (g) } & \multicolumn{3}{|c|}{ Rectal Temperature $\left({ }^{\circ} \mathrm{C}\right)$} & \multicolumn{3}{|c|}{ Packed Cell Volume (\%) } \\
\hline & Day 0 & Day 4 & $\%$ Change & Day 0 & Day 4 & $\begin{array}{c}\% \\
\text { Change }\end{array}$ & Day 0 & Day 4 & $\begin{array}{c}\% \\
\text { Change }\end{array}$ \\
\hline $2 \%$ TW80 & $26.0 \pm 0.2$ & $22.1 \pm 0.6$ & -14.7 & $36.5 \pm 0.0$ & $33.0 \pm 0.2$ & -9.6 & $59.2 \pm 0.2$ & $48.6 \pm 0.9$ & -17.9 \\
\hline CQ 25 & $26.3 \pm 0.5$ & $29.2 \pm 0.6$ & $11.3^{\mathrm{a} 3}$ & $36.6 \pm 0.1$ & $36.5 \pm 0.1$ & $-0.0^{\mathrm{a} 3}$ & $57.2 \pm 0.5$ & $58.8 \pm 0.7$ & $2.7^{\mathrm{a} 3}$ \\
\hline RM-M 100 & $26.6 \pm 0.9$ & $26.8 \pm 0.9$ & $0.7^{\mathrm{a} 3, \mathrm{~b} 3, \mathrm{c} 1, \mathrm{~d} 3, \mathrm{e} 3, \mathrm{f3}, \mathrm{g} 3}$ & $36.4 \pm 0.2$ & $35.1 \pm 0.2$ & $-3.6^{\mathrm{a} 3, \mathrm{~b} 3, \mathrm{~d} 1, \mathrm{e} 1, \mathrm{f} 3, \mathrm{~g} 3}$ & $56.4 \pm 0.7$ & $50.2 \pm 0.5$ & $-10.9^{a 1, b 3}$ \\
\hline RM-M 200 & $26.8 \pm 0.9$ & $27.9 \pm 1.0$ & $3.9^{\mathrm{a} 3, \mathrm{~b} 3, \mathrm{~d} 3, \mathrm{e} 3, \mathrm{f} 3, \mathrm{~g} 3}$ & $36.4 \pm 0.1$ & $35.5 \pm 0.1$ & $-2.3^{\mathrm{a} 3, \mathrm{~b} 3, \mathrm{~d} 1, \mathrm{~g} 2}$ & $58.0 \pm 0.7$ & $52.2 \pm 0.8$ & $-10.0^{a 3, b 3}$ \\
\hline RM-M 400 & $26.5 \pm 1.0$ & $28.3 \pm 1.1$ & $6.6^{\mathrm{a} 3, \mathrm{~b} 3, \mathrm{e} 1, \mathrm{f} 3, \mathrm{~g} 3}$ & $36.6 \pm 0.0$ & $36.2 \pm 0.2$ & $-1.0^{\mathrm{a} 3, \mathrm{~b} 1, \mathrm{e} 1, \mathrm{f} 1, \mathrm{~g} 3}$ & $57.4 \pm 0.9$ & $52.2 \pm 0.5$ & $-9.0^{\mathrm{a} 3, \mathrm{~b} 3}$ \\
\hline RM-H 8.75 & $25.3 \pm 0.9$ & $26.6 \pm 0.9$ & $5.0^{\mathrm{a} 3, \mathrm{~b} 3, \mathrm{e} 1, \mathrm{~g} 3}$ & $36.2 \pm 0.0$ & $35.1 \pm 0.2$ & $-2.0^{\mathrm{a} 3, \mathrm{~b} 3, \mathrm{~g} 2}$ & $57.2 \pm 0.8$ & $51.2 \pm 0.7$ & $-10.4^{\mathrm{a} 3, \mathrm{~b} 3}$ \\
\hline RM-H 17.50 & $24.8 \pm 0.5$ & $26.8 \pm 0.9$ & $7.8^{\mathrm{a} 3, \mathrm{~b} 1, \mathrm{~g} 2}$ & $36.5 \pm 0.1$ & $35.8 \pm 0.1$ & $-1.9^{a 3, b 3, g 2}$ & $55.6 \pm 0.5$ & $50.0 \pm 0.5$ & $-10.0^{a 3, b 3}$ \\
\hline RM-H 35.00 & $26.1 \pm 0.6$ & $28.7 \pm 1.0$ & $10.0^{\mathrm{a} 3}$ & $36.6 \pm 0.1$ & $36.4 \pm 0.1$ & $-0.7^{\mathrm{a} 3}$ & $57.6 \pm 0.5$ & $52.4 \pm 0.6$ & $-9.0^{\mathrm{a} 3, \mathrm{~b} 3}$ \\
\hline
\end{tabular}

Data are expressed as mean $\pm \mathrm{SEM} ; n=5$; a: compared to 2\% TW80 (Tween 80 ) vehicle, b: compared to chloroquine, c: compared to RM-M 200, d: compared to RM-M 400, e: compared to RM-H 8.75, f: compared to RM-H 17.50, g: compared to RM-H 35.00; $1: p<0.05,2: p<0.01$, 3: $p<0.001$; CQ: chloroquine phosphate, RM-M: 80\% methanol extract of R. multifidus, RM-H: hydrodistilled extract of R. multifidus.

The analysis of the 4-day suppressive test results indicated that both leaf extracts of $R$. multifidus inhibited parasite multiplication in P. berghei-infected mice, confirming the potential of the plant extracts to prevent or mitigate a primary attack due to malaria. Furthermore, the extracts improved survival time, prevented weight loss, maintained rectal temperature, and ameliorated anemia of infected mice, indicating that the plant extracts have the capacity to reduce the overall pathogenic outcome of the parasite on the test groups $[15,16]$. In the 4 -day suppressive test, RM-H showed superior activity $(p<0.001)$, as compared to RM-M.

\subsection{Structural Elucidation of the Isolated Compound}

The phytochemical investigation of RM-H using a hexane-ethyl acetate $(5: 1)$ solvent system over a silica gel PTLC resulted in the isolation of a pale yellow irritating oil that solidified immediately at room temperature to a white crystalline powder. The white powder was further purified by silica gel PTLC using a mixture of ethyl acetate and hexane in a ratio of 3:2 as a solvent system to yield a compound designated as RM-H1 $\left(R_{f}=0.59\right)$. The HRMS of RM-H1 showed a pseudo-molecular ion $(\mathrm{M}+1)$ peak at 193.0496 amu (calc. $m / z 193.0495 \mathrm{amu}$ ), which corresponds to a relative molecular formula of $\mathrm{C}_{10} \mathrm{H}_{9} \mathrm{O}_{4}{ }^{+}$. The ${ }^{1} \mathrm{H}-\mathrm{NMR}$ spectrum of RM-H1 revealed the presence of four cyclobutane protons assigned to H-6a, H-6a' $(\delta 2.64,2 \mathrm{H}, \mathrm{m})$ and H-6b, H-6b' $(\delta 2.25,2 \mathrm{H}, \mathrm{m})$. Four furanone protons were also observed and assigned to $\mathrm{H}-3, \mathrm{H}-3^{\prime}(\delta 6.32,2 \mathrm{H}, \mathrm{d}, J=5.7 \mathrm{~Hz})$ and $\mathrm{H}-4, \mathrm{H}-4^{\prime}(\delta 8.28$, $2 \mathrm{H}, \mathrm{d}, \mathrm{J}=5.7 \mathrm{~Hz}$ ). The ${ }^{13} \mathrm{C}-\mathrm{NMR}$ spectrum of $\mathrm{RM}-\mathrm{H} 1$ displayed five signals representing 10 carbon atoms, an indication that the compound is a dimer. The DEPT-135 spectrum revealed the presence of two $\mathrm{CH}_{2}$ and four methine carbons. The signals at $\delta 171.8,156.5$, 121.1, and 90.44 were assigned to the lactone carbonyl (C-2 and C-2'), olefinic (C-4 and 
C- $\left.4^{\prime}\right),\left(\mathrm{C}-3\right.$ and $\left.\mathrm{C} 3^{\prime}\right)$ and methine (C-5 and C-5') carbons, respectively. The upfield peak at $\delta$ 23.8 was assigned to the methylene carbons of the cyclobutane ring at C- 6 and $\mathrm{C}-6^{\prime}$. The ${ }^{1} \mathrm{H}^{-}{ }^{1} \mathrm{H}$ COSY spectrum clearly showed a cross peak between $\mathrm{H}-3, \mathrm{H}-3^{\prime}$ and $\mathrm{H}-4, \mathrm{H}-4^{\prime}$. A further spin-spin coupling between H-6a, H-6a' and H-6b, H-6 $\mathrm{b}^{\prime}$ is also apparent in the spectrum. The complete assignments of ${ }^{1} \mathrm{H}$ and ${ }^{13} \mathrm{C}$ chemical shifts of RM-H1 are listed in Table 3. From the chemical shifts presented and by comparing the ${ }^{1} \mathrm{H}$ and ${ }^{13} \mathrm{C}-\mathrm{NMR}$ spectral data of RM-H1 with the compound reported earlier [17], RM-H1 was characterized as anemonin (Figure 1).

Table 3. Comparison of the ${ }^{1} \mathrm{H}-\mathrm{NMR}$ and ${ }^{13} \mathrm{C}-\mathrm{NMR}$ spectral data of the RM-H1 with ${ }^{1} \mathrm{H}-\mathrm{NMR}$ and ${ }^{13} \mathrm{C}-\mathrm{NMR}$ of anemonin reported earlier [17].

\begin{tabular}{ccccc}
\hline \multirow{2}{*}{ No. } & ${ }^{1} \mathbf{H}$ NMR Chemical Shift $(\boldsymbol{\delta}, \mathbf{p p m})$ & \multicolumn{2}{c}{${ }^{13}$ C NMR Chemical Shift $(\boldsymbol{\delta}, \mathbf{p p m})$} \\
\cline { 2 - 5 } Anemonin [17] & - & 171.8 & 170.8 \\
\hline $2-2^{\prime}$ & - & - & 121.1 & 121.1 \\
$3-3^{\prime}$ & $6.32, \mathrm{~d}(5.7 \mathrm{~Hz})$ & $6.30, \mathrm{~d}(5.6 \mathrm{~Hz})$ & 156.5 & 153.2 \\
$4-4^{\prime}$ & $8.28, \mathrm{~d}(5.7 \mathrm{~Hz})$ & $8.26, \mathrm{~d}(5.6 \mathrm{~Hz})$ & 90.44 & 90.3 \\
$5-5^{\prime}$ & - & - & 23.27 & 23.8 \\
$6-6^{\prime}$ & $6 \mathrm{a}-6 \mathrm{a}^{\prime}=2.64$ & $6 \mathrm{a}-6 \mathrm{a}^{\prime}=2.61, \mathrm{~m}$ & & \\
& $6 \mathrm{~b}-6 \mathrm{~b}^{\prime}=2.25$ & $6 \mathrm{~b}-6 \mathrm{~b}^{\prime}=2.24, \mathrm{~m}$ & 23 & \\
\hline
\end{tabular}

$\mathrm{d}=$ doublet, $\mathrm{m}=$ multiplet.

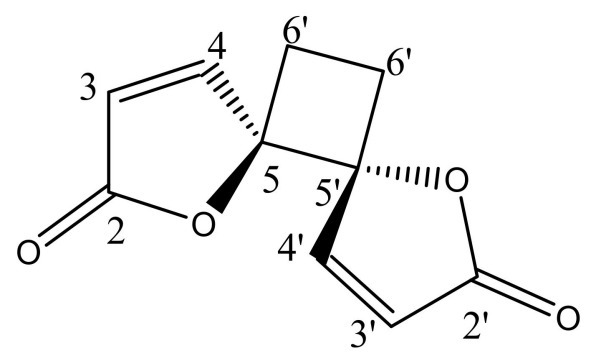

Figure 1. Structural formula of anemonin.

\subsection{Structural Elucidation of the Hydrolysis Product of Anemonin}

Two different hydrolysis products of anemonin were reported in the literature: 4,7dioxo-2-decenedioic acid with no details as to hydrolysis and structure determination [18] and sodium 2-(10E) 2'-sodium-carboxylate-vinyl)- 5-oxocyclohex-1-en carboxylate [19]. Since the hydrolysis of anemonin may occur in culture media and will influence activity, $90 \mathrm{mg}$ of the isolated anemonin was subjected to hydrolysis by sodium hydroxide in methanol, following the procedure of Nono et al. [19]. The TLC monitoring showed that the decomposition of anemonin only began at an elevated temperature, as reported [19]. After acidification, extraction, and HPLC, $20 \mathrm{mg}$ of a slightly yellow powder was isolated, which proved to be the acid corresponding to the disodium salt reported by Nono et al. [19]. The exact mass was determined by ESI-MS to be $233.0416 \mathrm{amu}(\mathrm{z}=1)$, which corresponds to the expected mass of the mono sodium salt (calc for $\mathrm{C}_{10} \mathrm{H}_{10} \mathrm{O}_{5} \mathrm{Na}^{+}\left[\mathrm{M}+\mathrm{H}^{+}\right]$: $233.0420 \mathrm{amu}$ ). ${ }^{1} \mathrm{H}$ NMR $\left(\mathrm{CD}_{3} \mathrm{OD}\right): 6.86(\mathrm{~d}, 1 \mathrm{H}, J=15 \mathrm{~Hz}), 6.16(\mathrm{~d}, 1 \mathrm{H}, J=15 \mathrm{~Hz}), 3.21(\mathrm{~s}, 2 \mathrm{H}), 2.88(\mathrm{~m}, 2 \mathrm{H})$, $2.47(\mathrm{~m}, 2 \mathrm{H}) .{ }^{13} \mathrm{C}$ NMR $\left(\mathrm{CD}_{3} \mathrm{OD}, \mathrm{DMSO}-\mathrm{d} 6\right)$ : 208.7, 171.7, 167.8, 167.6, 136.0, 133.7, 126.1, 33.6, 28.4, 28.3 .

\subsection{Acute Oral Toxicity of Anemonin}

Results of the present study showed that anemonin and RM-H have similar oral acute toxicity profiles. Thus, the $\mathrm{LD}_{50}$ of anemonin was determined to be more than $175 \mathrm{mg} / \mathrm{kg}$ but less than $550 \mathrm{mg} / \mathrm{kg}$. Anemonin was reported to be toxic to primary keratinocytes above a concentration of $25 \mu \mathrm{g} / \mathrm{mL}$ in in vitro 3-(4,5-dimethylthiazole-2-yl)2,5-diphenyltetrazolium bromide (MTT) assay [20]. 


\subsection{Antimalarial Activity of Anemonin}

\subsubsection{Four-Day Suppressive Test}

The results of the 4-day suppressive test indicated that anemonin significantly reduced parasitemia ( $p<0.001)$, as compared to the negative control group, with the percentage of suppression ranging from $78.3 \%$ to $83.0 \%$ (Table 4 and Supplementary Materials). However, all doses of anemonin exhibited significantly lower $(p<0.001)$ parasitemia reduction, as compared to the positive control group. Moreover, all test substances prolonged the MST significantly $(p<0.001)$, as compared to the negative control group. However, the MST was still significantly smaller $(p<0.001)$ than that of the standard drug chloroquine. Overall, significant statistical differences were not observed among doses of anemonin.

Table 4. Antimalarial activity of anemonin in mice infected with Plasmodium berghei in 4-day suppressive test.

\begin{tabular}{cccc}
\hline $\begin{array}{c}\text { Test Substance } \\
\text { (mg/kg/day) }\end{array}$ & \% Parasitemia & \% Suppression & $\begin{array}{c}\text { Mean Survival Time } \\
\text { (in Days) }\end{array}$ \\
\hline 2\% TW80 & $26.6 \pm 0.8$ & - & $9.2 \pm 0.4$ \\
Chloroquine & $0.1 \pm 0.3^{\mathrm{a} 1}$ & 99.5 & $28.0 \pm 0.0^{\mathrm{a} 1}$ \\
Anemonin 8.75 & $5.7 \pm 0.1^{\mathrm{a} 1, \mathrm{~b} 1}$ & 78.3 & $14.0 \pm 0.3^{\mathrm{a} 1, \mathrm{~b} 1}$ \\
Anemonin 17.50 & $5.2 \pm 0.1^{\mathrm{a} 1, \mathrm{~b} 1}$ & 80.1 & $14.4 \pm 0.2^{\mathrm{a} 1, \mathrm{~b} 1}$ \\
Anemonin 35.00 & $4.5 \pm 0.0^{\mathrm{a} 1, \mathrm{~b} 1}$ & 83.0 & $14.8 \pm 0.4^{\mathrm{a} 1, \mathrm{~b} 1}$
\end{tabular}

Data are expressed as mean \pm SEM; $n=5$; a: compared to $2 \%$ TW80 (Tween 80 ) vehicle, b: compared to CQ, 1 : $p<0.001 ; \mathrm{CQ}$ : chloroquine phosphate.

The 4-day suppressive test results showed that anemonin prevented the reduction of body weight significantly $(p<0.001)$, as compared to the negative control group (Table 5$)$. All doses of anemonin significantly prevented $(p<0.001)$ the reduction of body (rectal) temperature due to an infection with $P$. berghei, as compared to the negative control group. Anemonin also displayed statistically comparable effects with the standard drug in temperature stabilization. Anemonin showed protection of RBCs from P. berghei-infectionassociated anemia $(p<0.001)$, as compared to the negative control group. However, its effect was lower $(p<0.001)$ than that of chloroquine.

Table 5. Effect of anemonin on body weight, rectal temperature, and packed cell volume of mice infected with Plasmodium berghei in four-day suppressive antimalarial test.

\begin{tabular}{cccccccccc}
\hline \multirow{2}{*}{$\begin{array}{c}\text { Test Substances } \\
\text { (mg/kg/day) }\end{array}$} & \multicolumn{3}{c}{ Body Weight (g) } & \multicolumn{3}{c}{ Rectal Temperature $\left({ }^{\circ} \mathbf{C}\right)$} & \multicolumn{3}{c}{ Packed Cell Volume (\%) } \\
\cline { 2 - 11 } & Day 0 & Day 4 & $\begin{array}{c}\text { \% } \\
\text { Change }\end{array}$ & Day 0 & Day 4 & $\begin{array}{c}\text { \% } \\
\text { Change }\end{array}$ & Day 0 & Day 4 & \% \\
Change
\end{tabular}

Data are expressed as mean \pm SEM; $n=5$; a: compared to 2\% TW80 (Tween 80) vehicle, b: compared to CQ; 1: $p<0.05,2: p<0.01,3$ : $p<0.001$; CQ: chloroquine phosphate.

\subsubsection{Rane's Test}

As shown in Figure 2, Rane's test resulted in a gradual escalation of parasitemia throughout the course of treatment in the anemonin-treated groups (Figure 2). A repeated measures two-way ANOVA analysis of parasitemia showed a significant $(p<0.001)$ difference in parasite development across the course of treatment. At all dose levels, anemonin treatment resulted in a significant $(p<0.001)$ reduction of parasitemia, as compared to the negative control group, but the effect was less than the positive control group (Table 6 and Supplementary Materials). The efficacy of anemonin in mice at all doses was correlated 
significantly $(p<0.001)$ with an increased MST, as compared to the untreated control animals. However, increases in the MST of the chloroquine-treated group was significantly $(p<0.001)$ higher than that of anemonin-treated group.

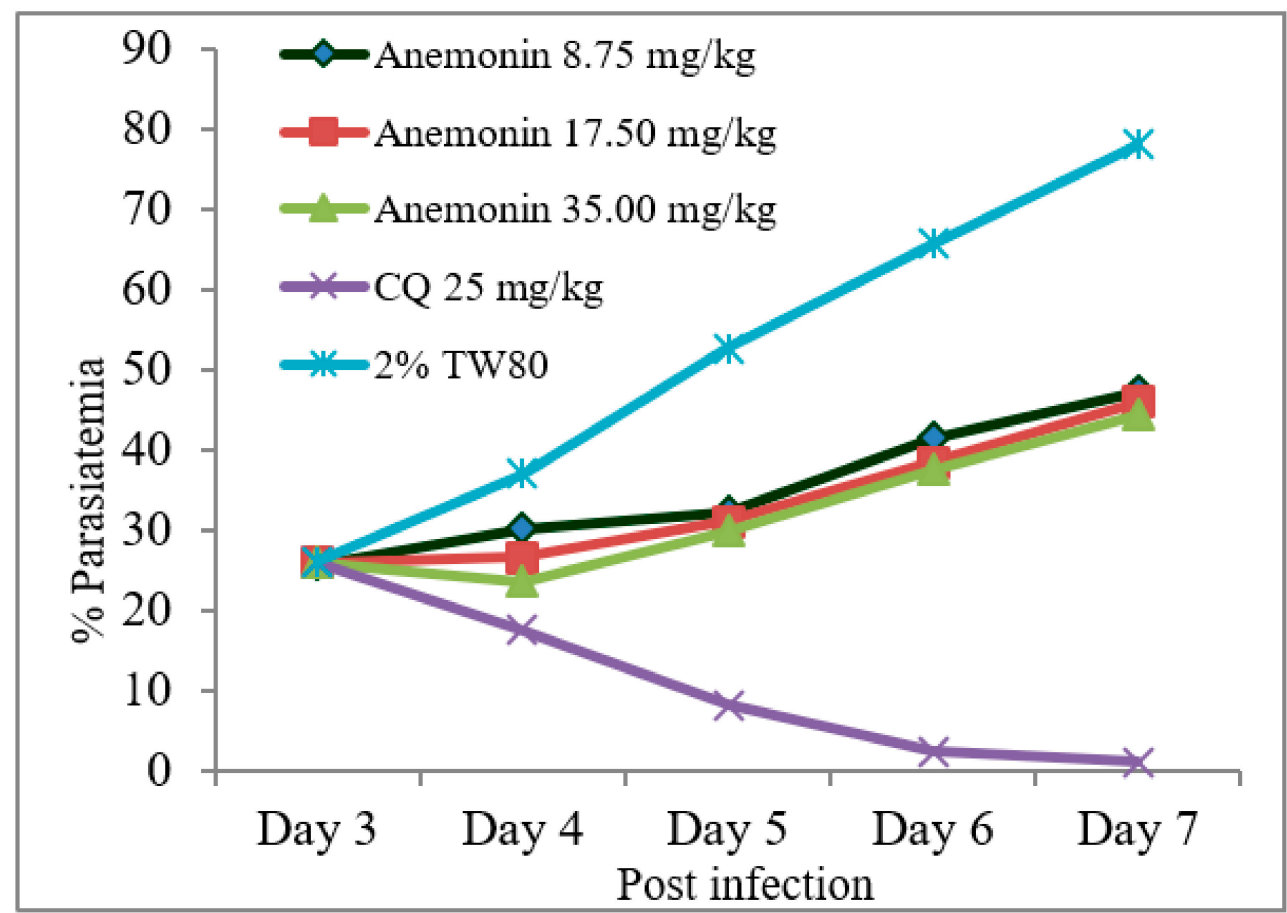

Figure 2. Parasitemia development over the course of treatment with anemonin on Plasmodium berghei-infected mice in Rane's antimalarial test (CQ; chloroquine, 2\% TW80: 2\% Tween 80).

Table 6. Antimalarial activity of anemonin in Plasmodium berghei-infected mice in Rane's test.

\begin{tabular}{cccc}
\hline $\begin{array}{c}\text { Test Substances } \\
\text { (mg/kg/day) }\end{array}$ & \% Parasitemia & \% Suppression & $\begin{array}{c}\text { Mean survival Time } \\
\text { (in Days) }\end{array}$ \\
\hline 2\% TW80 & $78.0 \pm 0.2$ & - & $8.6 \pm 0.1$ \\
CQ 25 & $1.1 \pm 0.2^{\mathrm{a} 1}$ & 98.4 & $28.0 \pm 0.0^{\mathrm{a} 1}$ \\
Anemonin 8.75 & $47.2 \pm 0.4^{\mathrm{a} 1, \mathrm{~b} 1}$ & 38.8 & $11.6 \pm 0.2^{\mathrm{a} 1, \mathrm{~b} 1}$ \\
Anemonin 17.50 & $45.9 \pm 0.8^{\mathrm{a} 1, \mathrm{~b} 1}$ & 40.5 & $12.0 \pm 0.3^{\mathrm{a} 1, \mathrm{~b} 1}$ \\
Anemonin 35.00 & $44.3 \pm 0.7^{\mathrm{a} 1, \mathrm{~b} 1}$ & 42.6 & $13.0 \pm 0.3^{\mathrm{a} 1, \mathrm{~b} 1}$ \\
\hline
\end{tabular}

Data are expressed as mean \pm SEM; $n=5$; a: compared to $2 \%$ TW80 (Tween 80 ) vehicle, b: compared to CQ; 1 $p<0.001$; CQ: chloroquine phosphate.

All the tested doses of anemonin protected against body weight loss significantly $(p<0.001)$, as compared to the negative control group, but the effect of chloroquine was superior $(p<0.001)$ to that of anemonin. Similarly, anemonin prevented the reduction of body temperature in the mice, and the effect was statistically significant $(p<0.001)$, as compared to the negative control group. There was no statistical difference between anemonin, at all dose levels, and chloroquine on improving body temperatures of the mice. As shown in Table 7, when anemonin was administered to P. berghei-infected mice, a substantial improvement of the PCV was observed, as compared with the infected, untreated group. Overall, in established infections of P. berghei, anemonin provided significant suppression of parasitemia and maintained pathological parameters, which suggests a curative potential for the compound. 
Table 7. Body weight, rectal temperature, and packed cell volume of Plasmodium berghei-infected mice treated with anemonin in Rane's antimalarial test.

\begin{tabular}{|c|c|c|c|c|c|c|c|c|c|}
\hline \multirow[b]{2}{*}{$\begin{array}{l}\text { Test Substances } \\
\text { (mg/kg/day) }\end{array}$} & \multicolumn{3}{|c|}{ Body Weight (g) } & \multicolumn{3}{|c|}{ Rectal Temperature $\left({ }^{\circ} \mathrm{C}\right)$} & \multicolumn{3}{|c|}{ Packed Cell Volume (\%) } \\
\hline & Day 3 & Day 7 & $\begin{array}{c}\% \\
\text { Change }\end{array}$ & Day 3 & Day 7 & $\begin{array}{c}\% \\
\text { Change }\end{array}$ & Day 3 & Day 7 & $\begin{array}{c}\% \\
\text { Change }\end{array}$ \\
\hline $2 \%$ TW 80 & $26.6 \pm 0.4$ & $20.5 \pm 0.8$ & -22.8 & $36.6 \pm 0.2$ & $32.2 \pm 0.3$ & -11.8 & $58.2 \pm 0.3$ & $46.2 \pm 0.4$ & -20.6 \\
\hline CQ 25 & $26.3 \pm 0.7$ & $27.3 \pm 0.7$ & $3.8^{\mathrm{a} 1}$ & $36.8 \pm 0.0$ & $36.3 \pm 0.1$ & $-1.3^{\mathrm{a} 1}$ & $58.0 \pm 0.7$ & $53.0 \pm 0.7$ & $-8.6^{\mathrm{a} 1}$ \\
\hline Anemonin 8.75 & $26.4 \pm 0.8$ & $23.6 \pm 0.7$ & $-10.7^{b 1}$ & $36.7 \pm 0.1$ & $35.6 \pm 0.2$ & $-2.7^{\mathrm{a} 1}$ & $57.8 \pm 0.5$ & $51.4 \pm 0.7$ & $-10.6^{\mathrm{a} 1}$ \\
\hline Anemonin 17.50 & $28.5 \pm 0.3$ & $27.2 \pm 1.1$ & $-3.9^{\mathrm{a} 1, \mathrm{~b} 1}$ & $36.7 \pm 0.1$ & $36.2 \pm 0.0$ & $-1.3^{\mathrm{a} 1}$ & $56.0 \pm 0.7$ & $50.2 \pm 0.8$ & $-10.3^{\mathrm{a} 1}$ \\
\hline Anemonin 35.00 & $26.3 \pm 0.7$ & $25.3 \pm 0.7$ & $-3.8^{\mathrm{a} 1, \mathrm{~b} 1}$ & $36.8 \pm 0.0$ & $36.3 \pm 0.3$ & $-1.3^{\mathrm{a} 1}$ & $58.1 \pm 0.7$ & $53.0 \pm 0.7$ & $-8.7^{a} 1$ \\
\hline
\end{tabular}

Data are expressed as mean \pm SEM; $n=5$; a: compared to 2\% TW80 (Tween 80) vehicle, b: compared to CQ; $1: p<0.001$; CQ: chloroquine phosphate.

\subsubsection{Prophylactic Test}

In the prophylactic test, all the tested doses of anemonin significantly $(p<0.001)$ suppressed parasitemia, as compared to the negative control group (Table 8). However, the effect of anemonin was significantly $(p<0.001)$ lower than the chemosuppression displayed by the positive control group. Similarly, anemonin caused significant $(p<0.001)$ prolongation of the MST, as compared to the negative control groups, although chloroquine was more effective $(p<0.001)$ than anemonin (Table 8 and Supplementary Materials).

Table 8. Prophylactic antimalarial activity of anemonin in Plasmodium berghei-infected mice.

\begin{tabular}{cccc}
\hline $\begin{array}{c}\text { Test Substances } \\
\text { (mg/kg/day) }\end{array}$ & \% Parasitemia & \% Suppression & $\begin{array}{c}\text { Mean Survival Time } \\
\text { (in Days) }\end{array}$ \\
\hline 2\% TW80 & $33.8 \pm 0.9$ & - & $8.4 \pm 0.5$ \\
CQ 25 & $3.8 \pm 0.7^{\mathrm{a} 1}$ & 88.6 & $27.4 \pm 0.4^{\mathrm{a} 1}$ \\
Anemonin 8.75 & $13.1 \pm 0.4^{\mathrm{a} 1, \mathrm{~b} 1}$ & 60.7 & $14.0 \pm 0.3^{\mathrm{a} 1, \mathrm{~b} 1}$ \\
Anemonin 17.50 & $12.1 \pm 0.5^{\mathrm{a} 1, \mathrm{~b} 1}$ & 63.7 & $14.0 \pm 0.3^{\mathrm{a} 1, \mathrm{~b} 1}$ \\
Anemonin 35.00 & $11.1 \pm 0.3^{\mathrm{a} 1, \mathrm{~b} 1}$ & 66.7 & $14.4 \pm 0.2^{\mathrm{a} 1, \mathrm{~b} 1}$ \\
\hline
\end{tabular}

Data are expressed as mean \pm SEM; $n=5$; a: compared to $2 \%$ TW80 (Tween 80 ) vehicle, b: compared to CQ; $p<0.001 ; \mathrm{CQ}$ : chloroquine phosphate.

Treatment with anemonin significantly prevented body weight loss associated with parasitemia at all dose levels on day 7 , as compared to body weight on day 3 . The results also revealed that anemonin-treated groups at all dose levels significantly $(p<0.001)$ prevented the loss of body weight, as compared to that of the negative control group. Similarly, anemonin significantly attenuated $(p<0.001)$ the rapid decline in rectal temperature of infected mice, as compared to the negative control group, and there were no statistical differences between the effects of anemonin and chloroquine. In addition, anemonin prevented the reduction of PCV significantly $(p<0.001)$ due to the parasite infection, as compared with the negative control group. The effect of a higher dose of anemonin (35.00 mg/kg/day) was comparable with that of chloroquine (Table 9).

An increase in parasitemia levels in rodents usually results in decreased metabolic rates, and they develop severe hypothermia [15], which may result in death. The decrease in body weight caused by malaria has been associated with decreased food intake, disturbed metabolic function, and hypoglycemia [15]. An ideal antimalarial agent would, therefore, prevent this occurrence. In the current study, anemonin showed temperature stabilizing and weight maintenance effects in all models. In addition to parasite suppression, this may indicate that anemonin controlled the immune system of the infected mice as well as controlled some of the pathological processes and balanced the reduction of the metabolic rate that produces the drop in rectal temperature. 
Table 9. Body weight, rectal temperature, and packed cell volume of Plasmodium berghei-infected mice treated with anemonin in prophylactic antimalarial test.

\begin{tabular}{|c|c|c|c|c|c|c|c|c|c|}
\hline \multirow{2}{*}{$\begin{array}{c}\text { Test } \\
\text { Substances } \\
\text { (mg/kg/day) }\end{array}$} & \multicolumn{3}{|c|}{ Body Weight (g) } & \multicolumn{3}{|c|}{ Rectal Temperature $\left({ }^{\circ} \mathrm{C}\right)$} & \multicolumn{3}{|c|}{ Packed Cell Volume (\%) } \\
\hline & Day 3 & Day 7 & $\%$ Change & Day 3 & Day 7 & $\begin{array}{c}\% \\
\text { Change }\end{array}$ & Day 3 & Day 7 & $\begin{array}{c}\% \\
\text { Change }\end{array}$ \\
\hline $2 \%$ TW80 & $26.7 \pm 0.5$ & $21.6 \pm 0.0$ & -19.0 & $36.6 \pm 0.0$ & $32.5 \pm 0.2$ & -11.2 & $58.9 \pm 0.4$ & $47.8 \pm 0.6$ & -18.8 \\
\hline CQ 25 & $26.1 \pm 0.6$ & $27.9 \pm 0.5$ & $6.8^{\mathrm{a} 2}$ & $36.7 \pm 0.1$ & $36.5 \pm 0.1$ & $-0.3^{\mathrm{a} 2}$ & $57.8 \pm 0.5$ & $53.4 \pm 0.8$ & $-7.6^{\mathrm{a} 2}$ \\
\hline Anemonin 8.75 & $26.4 \pm 0.8$ & $23.6 \pm 0.7$ & $-10.7^{\mathrm{a} 2, \mathrm{~b} 2}$ & $36.7 \pm 0.1$ & $35.6 \pm 0.2$ & $-2.7^{\mathrm{a} 2}$ & $58.4 \pm 0.6$ & $51.0 \pm 0.4$ & $-12.6^{\mathrm{a} 2, \mathrm{~b} 1}$ \\
\hline Anemonin 17.50 & $27.4 \pm 0.5$ & $27.5 \pm 0.4$ & $0.3^{\mathrm{a} 2, \mathrm{~b} 2}$ & $36.5 \pm 0.1$ & $36.1 \pm 0.2$ & $-1.0^{\mathrm{a} 2}$ & $58.0 \pm 0.5$ & $50.8 \pm 0.3$ & $-12.4^{\mathrm{a} 2, \mathrm{~b} 1}$ \\
\hline Anemonin 35.00 & $26.9 \pm 0.3$ & $27.2 \pm 0.5$ & $1.3^{\mathrm{a} 2, \mathrm{~b} 2}$ & $36.5 \pm 0.2$ & $36.2 \pm 0.0$ & $-0.7^{\mathrm{a} 2}$ & $58.6 \pm 0.5$ & $53.4 \pm 0.8$ & $-8.8^{\mathrm{a} 2}$ \\
\hline
\end{tabular}

Data are expressed as mean \pm SEM; $n=5$; a: compared to 2\% TW80 (Tween 80) vehicle, b: compared to CQ; 1: $p<0.05,2: p<0.001$; CQ: chloroquine phosphate.

As shown in Figure 3, the effective median dose $\left(\mathrm{ED}_{50}\right)$ of anemonin was determined by a non-linear regression analysis from sigmoidal dose-response curves using Graphpad Prism 8.0 software. This revealed that the $\mathrm{ED}_{50} \mathrm{~s}$ of anemonin are $0.4172,0.5356$, and $0.5196 \mathrm{mg} / \mathrm{kg}(2.17,2.78$, and $2.70 \mu \mathrm{M})$ in the 4-day suppressive, Rane's, and prophylactic tests, respectively.

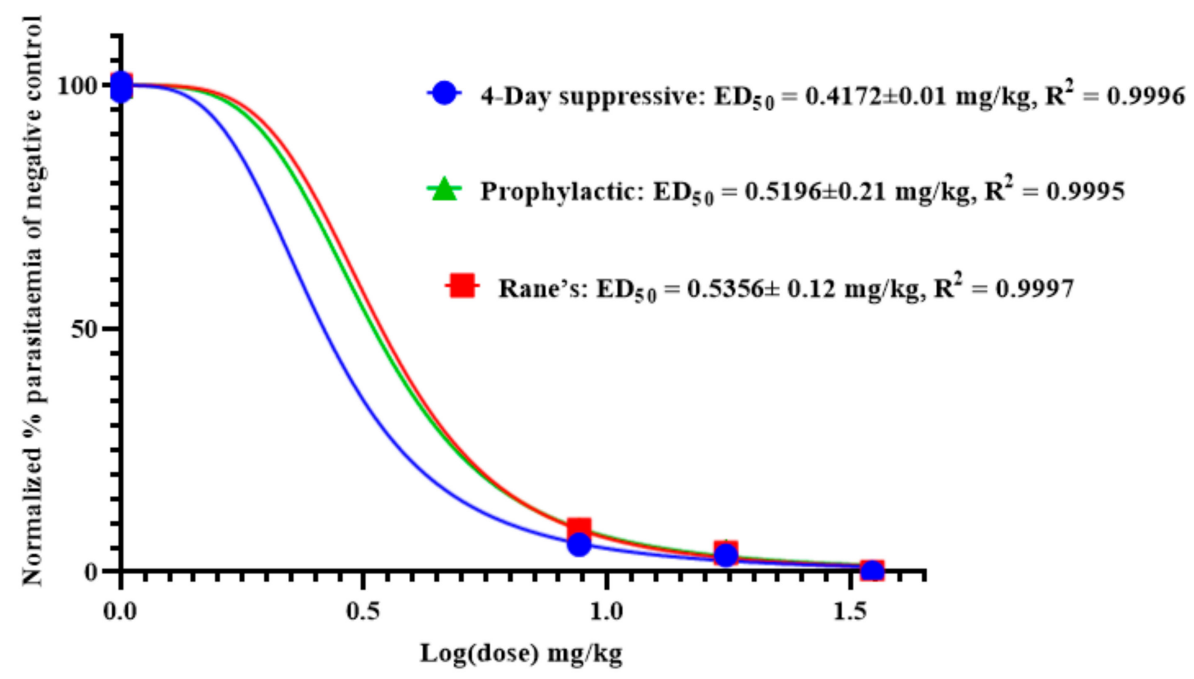

Figure 3. $\mathrm{ED}_{50}$ of anemonin in mice infected with Plasmodium berghei in 4-day suppressive, Rane's, and prophylactic antimalarial tests; $\mathrm{ED}_{50}$ was estimated from a plot of log dose against the percentage of parasitemia of negative control group (normalized); values are presented as mean $\pm \mathrm{SEM} ; n=5$.

Although there is an ongoing debate about the cut-off value for the potency of natural products, the industry standard for considering a pure compound to be active is generally accepted as $\mathrm{IC}_{50} \leq 10 \mu \mathrm{M}$ [21]. In this regard, anemonin can be considered a potent antimalarial compound with the potential to be developed into a viable antimalarial drug. Therefore, the use of anemonin as a template for designing novel antiplasmodial pharmacophores cannot be overemphasized.

The trophozoite stage of the malarial parasite in human erythrocytes exhibits an intense glutathione (GSH) metabolism, and many glutathione species occur in trophozoite cytosol, mainly GSH [22]. GSH is a water-soluble tripeptide composed of the amino acids glutamine, cysteine, and glycine, and it plays an important role as an antioxidative defense (scavenging free radicals generated by the parasite) as well as maintaining an environment to reduce cytosol, promoting rapid cell growth, and supporting many of the known GSH-dependent processes that are directly related to the specific lifestyle of the parasite $[22,23]$. All these are considered factors in the pathophysiology of malaria but also as potential drug targets [24,25]. Methylene blue, an inhibitor of the structurally known $P$. falciparum glutathione reductase, appears to be a promising antimalarial medication 
when given in combination with chloroquine [26,27]. Cysteine thiol acts as a nucleophile in reactions with both exogenous and endogenous electrophilic species [28,29]. As a consequence, reactive oxygen species are frequently targeted by GSH in both spontaneous and catalytic reactions [22,30]. Compounds containing an $\alpha, \beta$-unsaturated lactone, such as anemonin, undergo a specific alkylation involving unsaturated lactone with the thiol group (sulphydryl (-SH)) of L-cysteine (2) by a Michael-type addition [31-33].

In the present study, the observed antiprotozoal activity of anemonin might be by increasing oxidative stress in the parasite, since it interacts with the thiol group of the precursor amino acid L-cysteine, along with the cysteine residue of GSH itself by a Michaeltype addition (Figure 4). Meanwhile, L-cysteine is relevant as a substrate in the synthesis of GSH [34]. The capability of anemonin to interact with this important amino acid may suggest its potential to increase oxidative stress and inhibit growth in the parasites.

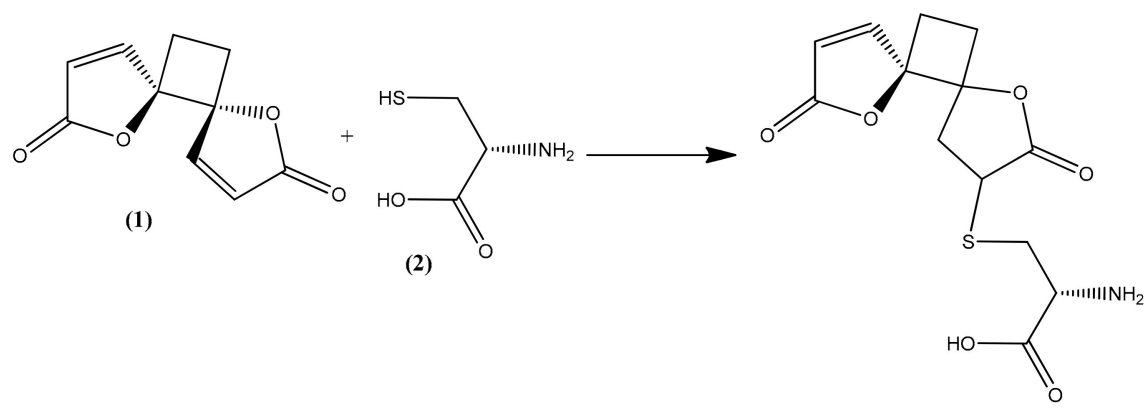

Figure 4. Possible Michael-type addition reaction between anemonin (1) and L-cysteine (2).

\subsection{Antimycobacterial Activity of Anemonin}

Since $R$. multifidus is also traditionally used for the treatment of tuberculosis and tuberculosis-like lung infections, anemonin was tested for in vitro activity against two mycobacterial species: viz. Mycobacterium smegmatis, which is a good model for M. tuberculosis, and the fast-growing M. abscessus, which is an emergent health threat, especially for people with lung problems. The antimycobacterial activity was determined against $M$. abscessus ATCC 19977 and M. smegmatis $\mathrm{mc}^{2} 155$ [35]. Even with a concentration up to $100 \mu \mathrm{M}$, anemonin showed no growth inhibition in either fast-growing mycobacteria.

\section{Materials and Methods}

\subsection{Plant Material}

Fresh leaves of R. multifidus were collected from Dorze, a village located in Chencha woreda and part of the Gamo Gofa Zone (520 km southwest of Addis Ababa, Ethiopia), which is located in the Great Rift Valley, above the west shore of Lake Abaya, at $6^{\circ} 11^{\prime} 36^{\prime \prime} \mathrm{N}$ and $37^{\circ} 34^{\prime} 13^{\prime \prime} \mathrm{E}$. The plant material was authenticated by Ato Melaku Wondafrash, National Herbarium, Department of Biology, College of Natural and Computational Sciences, Addis Ababa University (AAU), where a botanical specimen was deposited (collection number BS-001) for future reference.

\subsection{Preparation of Ranunculus multifidus Leaf Extracts}

(1) Aqueous methanol extract, RM-M: Fresh leaves (2 kg) of R. multifidus were macerated with about $6 \mathrm{~L}$ of $80 \%$ methanol at room temperature for 9 days, and the filtrate was concentrated in a rotavapor (Heidolph Instruments $\mathrm{GmbH}$ and Co., Schwabach, Germany) at a temperature not exceeding $40^{\circ} \mathrm{C}$. The remaining aqueous solution was dried in a lyophilizer (Alpha 1-2LD plus Martin Christ Co. Ltd., Osterode, Germany) to yield 6.4\% $(w / w)$ of brown powder labeled as RM-M.

(2) Chloroform extract of hydrodistillate, RM-H: Fresh leaves $(1 \mathrm{~kg})$ of R. multifidus were chopped into small pieces and subjected to hydrodistillation for $3 \mathrm{~h}$ using a Clevengertype apparatus. The condensate was collected and extracted with $100 \mathrm{~mL}$ chloroform $(3 \times)$ and using a separatory funnel. About $5 \mathrm{~g}$ of ahydrous sodium sulfate was added to 
the combined organic solvent extract to remove moisture, and then it was filtered using Whatman No 1. filter paper. The organic solvent was concentrated in a rotavapor at a temperature not exceeding $35^{\circ} \mathrm{C}$ to yield $0.56 \%(w / w)$ pungent oil designated as RM-H.

\subsection{Chemicals}

Chromatographic separation was performed by preparative TLC Silica gel 60 F254 (0.5 mm thick) (Loba Chemie Pvt. Ltd., Mumbai, India). $n$-Hexane, chloroform, ethyl acetate and methanol (Loba Chemie Pvt. Ltd., Mumbai, India), trisodium citrate (BDH Chemicals Ltd., London, UK), and Giemsa (ESJAY Chemicals, Maharashtra, India) were all used as received. Pure chloroquine phosphate supplied by Ethiopian Pharmaceuticals Manufacturing Sh. Co. (EPHARM, Addis Ababa, Ethiopia) was used as a reference drug.

\subsection{Preparative Thin Layer Chromatography}

Preparative thin layer chromatography (PTLC) was carried out using a mixture of $n$-hexane and ethyl acetate (5:1) as a mobile phase to analyze RM-H. The chromatograms were visualized using ultraviolet light (UV) at wavelength $254 \mathrm{~nm}$. The major band was carefully scrapped off the plates, washed with a mixture of chloroform and methanol (1:1), and then filtered and concentrated to dryness under reduced pressure. The white powder obtained, designated RM-H1, was further purified by PTLC using ethyl acetate-hexane (3:2) as a solvent system.

\subsection{Mass Spectrometry}

High-resolution mass spectra (HRMS) were recorded on an LTQ Orbitrap XL mass spectrometer (Thermo Fisher Scientific, Bremen, Germany) using nano-ESI (Proxeon, Odense, Denmark), and samples were loaded into self-pulled, gold-coated quartz emitters. Parameters included damping gases helium (purity 5.0, linear trap) and nitrogen (purity 5.0, curved trap). Ionization mode was positive. Mass range was $m / z$ 100-2000. No sheath and auxiliary gas (nano-ESI), no heated vaporizer, capillary temperature was $200{ }^{\circ} \mathrm{C}$, spray voltage was $1.3 \mathrm{kV}$, capillary voltage was $43 \mathrm{~V}$. Tube lens voltage was $100 \mathrm{~V}$ with max. injection time of $100 \mathrm{~ms}$.

\subsection{NMR}

NMR spectra were obtained at room temperature on a VNMRS $400 \mathrm{MHz}$ spectrometer (Agilent Technologies, Santa Clara, CA, USA) operating at $400 \mathrm{MHz}$ for ${ }^{1} \mathrm{H}$ and $100 \mathrm{MHz}$ for ${ }^{13} \mathrm{C}$ using deuterated dimethyl sulfoxide (DMSO) as a solvent. Chemical shifts are reported relative to the residual solvent peak of DMSO- $\mathrm{d}_{6}\left({ }^{1} \mathrm{H}=2.50 \mathrm{ppm},{ }^{13} \mathrm{C}=39.5 \mathrm{ppm}\right)$.

\subsection{Experimental Animals and Parasite}

White Swiss albino mice of either sex, weighing 22-30 g and aged 5-6 weeks, were employed throughout the experiment. The mice were obtained from the animal house of the Department of Pharmacology, School of Pharmacy (SoP), College of Health Sciences, AAU. The animals were held in stainless steel cages at room temperature with a $12 \mathrm{~h}$ light $/ 12 \mathrm{~h}$ dark cycle. They were provided with water and food pellets ad libitum in the animal house. All the experiments were conducted in accordance with internationally accepted laboratory animal use and care guideline [36] and were approved by the Institutional Review Board of SoP, AAU (approval code: ERB/SOP241b/13/2021). The chloroquinesensitive Plasmodium berghei ANKA strain was used for antimalarial assay. The parasites were subsequently maintained in the laboratory by serial blood passage from the infected mice to the non-infected ones on a weekly basis.

\subsection{Acute Oral Toxicity}

An acute oral toxicity study was conducted as per the internationally accepted protocol of the OECD Guideline 425 [37]. Fifteen healthy female non-pregnant and nulliparous mice aged 6-8 weeks and weighing 22-28 g were randomly assigned to 3 groups, each 
having 5 mice. All mice were fasted (food only) for $4 \mathrm{~h}$ before and $2 \mathrm{~h}$ after administration of the test substances. The test substances were dissolved in $2 \%$ Tween 80 ( $2 \%$ TW80). One mouse from each group was orally administered $2000 \mathrm{mg} / \mathrm{kg}$ of RM-M (Group 1), RM-H (Group 2), and RM-H1 (Group 3), consecutively. Then the mice were observed for general signs and symptoms of toxicity and mortality within $24 \mathrm{~h}$. The mouse receiving $2000 \mathrm{mg} / \mathrm{kg}$ of the RM-M (Group 1) survived, but the mouse from Group 2 and the mouse from Group 3 died $30 \mathrm{~min}$ after administration. Since no death was observed within $24 \mathrm{~h}, 2000 \mathrm{mg} / \mathrm{kg}$ of RM-M was administered to the remaining 4 mice in Group 1 . Then they were observed individually for general signs and symptoms of toxicity; physical or behavioral changes, such as loss of appetite, ruffled fur, lacrimation, and mortality; and other signs of toxicity. The observation was carried out for $4 \mathrm{~h}$ with $30 \mathrm{~min}$ intervals and then for 14 consecutive days with an interval of $24 \mathrm{~h} \mathrm{[37].}$

The main test was conducted for acute oral toxicity study of RM-H and RM-H1. Since there was no information regarding the $50 \%$ lethal dose $\left(\mathrm{LD}_{50}\right)$ and the slope of the doseresponse curve for both test substances, dosing was initiated at $175 \mathrm{mg} / \mathrm{kg}$ [37]. Twelve mice were grouped into two groups of six mice each, and one mouse from each group received $175 \mathrm{mg} / \mathrm{kg}$ of the test substances (RM-H (Group 1) and RM-H1 (Group 2)). Since the experimental animals survived for $48 \mathrm{~h}$, doses of the test substances were increased by a factor of 3.2 to $550 \mathrm{mg} / \mathrm{kg}$. Following this, $550 \mathrm{mg} / \mathrm{kg}$ of RM-H and RM-H1 were given to a second mouse from Group 1 and Group 2, respectively, which resulted in the death of both mice $4 \mathrm{~h}$ after administration. Therefore, the remaining 4 mice in Group 1 received $175 \mathrm{mg} / \mathrm{kg} /$ mouse of RM-H while those in Group 2 were given $175 \mathrm{mg} / \mathrm{kg} / \mathrm{mouse}$ of RM-H1. The mice were observed individually for general signs and symptoms of toxicity; physical or behavioral changes such as loss of appetite, ruffled fur, lacrimation, and mortality; and other signs of toxicity continuously for $4 \mathrm{~h}$ with $30 \mathrm{~min}$ intervals and then for 14 consecutive days with an interval of $24 \mathrm{~h}$ [37].

\subsection{In Vivo Antimalarial Assay}

\subsubsection{Inoculation of Mice}

The parasitemia of the donor mice was determined by preparing blood smears on microscope slides from blood film taken from the tails of infected mice [38]. The smear was fixed with methanol and stained with Giemsa to determine the parasitemia level of the donor under a microscope. When the parasitemia level was $30-40 \%$, parasitized erythrocytes were collected from the donor mouse by cardiac puncture using a sterile syringe and placed in a Petri dish containing an anticoagulant ( $0.5 \%$ trisodium citrate) and then immediately diluted with uninfected mouse blood and normal saline $(0.9 \%)$ in such way that the final volume contained $5 \times 10^{7}$ infected erythrocytes $/ \mathrm{mL}$ of blood [39]. The diluted blood $(0.2 \mathrm{~mL})$ was then injected into all the experimental mice intraperitoneally (IP) [40].

\subsubsection{4-Day Suppressive Test (Peter's Test)}

A four-day suppressive test with mice infected with chloroquine-sensitive P. berghei was employed according to the method described previously [41]. Fifty-five mice were injected with an inoculum of $1 \times 10^{7} P$. berghei-infected erythrocytes IP on the first day (day 0) [42]. Two h post-infection, the mice were randomly distributed into eleven groups, each containing five mice. Group 1 served as a negative control group (received vehicle $2 \%$ Tween $80,10 \mathrm{~mL} / \mathrm{kg} /$ day) and Group 2 as positive control group (received chloroquine, $25 \mathrm{mg} / \mathrm{kg} /$ day). The remaining nine groups were treatment groups. Groups 3-5 received 100,200 , and $400 \mathrm{mg} / \mathrm{kg} /$ day of RM-M, respectively, while Groups 6-8 and Groups 9-11 received $8.75,17.50$, and $35.00 \mathrm{mg} / \mathrm{kg} /$ day $\mathrm{RM}-\mathrm{H}$ and $\mathrm{RMH}-1$, respectively. All test substances were administered orally using oral gavage, and the doses were determined based on the acute oral toxicity test results. The middle dose was one tenth of the safe dose ( $2000 \mathrm{mg} / \mathrm{kg}$ for RM-M and $\sim 175 \mathrm{mg} / \mathrm{kg}$ for RM-H and RM-H1). The higher dose was twice the middle dose, and the lower dose was half of the middle dose [43,44]. Treatment 
was started $3 \mathrm{~h}$ post-infection on day 0 and continued for an additional three consecutive days at 24, 48, and $72 \mathrm{~h}$ post-infection (until day 3). On day 4 of the experiment (at $96 \mathrm{~h}$ post-infection), blood was collected from the tail of each mouse, and a thin smear was prepared on a microscope slide to determine parasitemia [45]. In addition, body weight, rectal temperature, and PCV were measured just before infection and at the end of the experiment [46]. Afterwards, mice were observed for 28 days (day 0-27) to determine the MST for each group [47].

\subsubsection{Rane's Test}

Rane's test, which evaluates the curative potential of RM-H1, was performed using the method described earlier [48]. Twenty-five mice were injected IP with an inoculum of $1 \times 10^{7}$ P. berghei-infected erythrocytes on the first day (Day 0) [49]. At day 3, the animals were randomly divided into five groups with five mice in each group. Group 1 served as the negative control group and received the vehicle ( $2 \%$ Tween $80,10 \mathrm{~mL} / \mathrm{kg} /$ day), and Group 2 served as the positive control group and received chloroquine at $25 \mathrm{mg} / \mathrm{kg} /$ day. Groups 3-5 were treated with 8.75, 17.50, and $35.00 \mathrm{mg} / \mathrm{kg} /$ day RM-H1, respectively. Treatment continued for a further 3 days (i.e., 96, 120, and $144 \mathrm{~h}$ post-infection) [50]. Parasitemia levels were recorded daily throughout the experiment starting at day 3 [51]. PCVs, rectal temperatures, and body weights were measured just before the first dose (day 3) and at the end of the experiment (day 7). Thereafter, all groups were observed for 28 days, and their survival times were recorded [52].

\subsubsection{Prophylactic Test}

Investigation of the prophylactic potential of RM-H1 was done following the method described previously [53]. Twenty-five mice were randomly assigned into five groups of five mice each. Group 1, which served as negative control received vehicle (2\% TW80, $10 \mathrm{~mL} / \mathrm{kg} /$ day) and Group 2 (the positive control group) received chloroquine $25 \mathrm{mg} / \mathrm{kg} /$ day. Groups 3-5 were treated with $8.75,17.50$ and $35.00 \mathrm{mg} / \mathrm{kg} /$ day of RM-H1, respectively. Treatment was given orally for 3 days, $24 \mathrm{~h}$ after the last treatment (day 0), all mice were infected with an inoculum of $1 \times 10^{7} \mathrm{P}$. berghei-infected blood [45,49]. Seventy-two $\mathrm{h}$ post-infection (day 3), blood smears were prepared from each mouse and the parasitemia level was determined [50]. PCV rectal temperature and body weight were measured just before parasite inoculation (day 0) and at the end of the experiment (day 3) [51]. Finally, the groups were followed for 28 days in order to record their survival time [52].

\subsection{Determination of Parasitemia and Survival Time}

Blood from each mouse was applied as a thin smear onto different microscope slides. Then the smear was fixed with methanol for $15 \mathrm{~min}$ and stained with $10 \%$ Giemsa for $15 \mathrm{~min}$. The slides were washed with tap water and dried at room temperature. The number of parasite-infected RBCs were counted using a light microscope with an oil immersion objective lens at a magnification power of $100 \times$. Parasitemia was determined by counting a minimum of three fields per slide. The percent of parasitemia and percent of inhibition were calculated by the following Peters-Robinson formula [54].

$$
\% \text { Parasitemia }=\frac{\text { Number of parasitized RBC }}{\text { Total number of RBC count }} \times 100
$$

$\%$ Suppression $=\frac{\% \text { Parasitemia in negative control }-\% \text { Parasitemia in the study group }}{\% \text { Parasitemia in negative control }} \times 100$

The MST was determined using the formula indicated below:

$$
\text { Mean survival time (MST) }=\frac{\text { Sum of survival time of all mice in a group (daily) }}{\text { Total number of mice in the group }}
$$




\subsection{Determination of Packed Cell Volume, Rectal Temperature, and Body Weight}

Blood was collected from the tail of each mouse in heparinized microhematocrit capillary tubes, filling up to three-fourths of the tube, and then the tube was sealed at the dry end with sealing clay. The tubes were then placed in a microhematocrit centrifuge with the sealed ends out wards. The blood was centrifuged at 12,000 rpm for $10 \mathrm{~min}$. The PCV was determined using the following formula.

$$
\mathrm{PCV}=\frac{\text { Volume of erythrocytes in a given volume of blood }}{\text { Total blood volume }} \times 100
$$

All mice were weighed using a sensitive digital weighing balance, and a digital rectal thermometer was used to measure rectal temperature. The percentage changes of mean values of all three parameters that occurred before and after treatment were then calculated.

$$
\% \text { Change }=\frac{\text { Mean on final day }- \text { Mean on initial day }}{\text { Mean on final day }} \times 100
$$

\subsection{In Vitro Antimycobacterial Assay}

The MICs were determined against M. smegmatis $\mathrm{mc}^{2} 155$ pTEC27 and M. abscessus ATCC 19977 pTEC27 by the broth microdilution method with 96-Well flat-bottom tissue culture plates (Sarstedt, 83.3924.500) [35]. In the third well of each row, two times of the desired highest concentration of the tested compound was added in a 7H9 medium supplemented with $10 \%$ ADS and $0.05 \%$ polysorbate 80 . Each compound was diluted twofold in a ten-point serial dilution. The concentration of the starting inoculum was $5 \times 10^{5}$ cells $\mathrm{mL}^{-1}$. The starting inoculum was diluted from a preculture at the mid-log phase $\left(\mathrm{OD}_{600} 0.3\right.$ to 0.7$)$, and an $\mathrm{OD}_{600}$ of 0.1 was correlated to $1 \times 10^{8} \mathrm{CFU} \mathrm{mL} \mathrm{mL}^{-1}$. The plates were sealed with parafilm, placed in a container with moist tissue, and incubated for three days at $37^{\circ} \mathrm{C}$. Each plate had eight negative controls [ $1 \%$ dimethyl sulfoxide (DMSO)] and eight positive controls (100 $\mu \mathrm{M}$ amikacin). After incubation, the plates were monitored by OD measurement at $590 \mathrm{~nm}$ (Tecan SpectraFluor). The assay was performed in duplicate, and the results were validated by RFP measurement.

Every assay plate contained eight wells with $1 \%$ DMSO as a negative control, which corresponds to $100 \%$ bacterial growth, and eight wells with amikacin $(100 \mu \mathrm{M})$ as a positive control, in which $100 \%$ inhibition of bacterial growth was reached. The controls were used to monitor the assay quality through determination of the z-score. The z-factor was calculated as follows:

$$
\mathrm{Z}^{\prime}=1-\frac{3\left(\mathrm{SD}_{\mathrm{amikacin}}+\mathrm{SD}_{\mathrm{DMSO}}\right)}{\mathrm{M}_{\text {amikacin }}-\mathrm{M}_{\mathrm{DMSO}}}
$$

where SD stands for standard deviation and $\mathrm{M}$ for mean.

The percentage of growth inhibition was calculated by the equation:

$$
\% \text { Growth inhibition }=-100 \% \times \frac{\mathrm{OD}_{590}(\text { sample })-\mathrm{OD}_{590}(\mathrm{DMSO})}{\mathrm{OD}_{590}(\mathrm{DMSO})-\mathrm{OD}_{590}(\text { amikacin })}
$$

where OD represents optical density.

\subsection{Statistical Analysis}

The data analysis was carried out using IBM SPSS (Statistical Package for Social Sciences) Statistics for Windows, Version 25.0. The results were expressed as mean \pm standard error of mean $(\mathrm{M} \pm \mathrm{SEM})$. Statistical significance was determined by a one-way ANOVA followed by the Tukey post hoc test to compare different parameters among the treatment and control groups. A result of $p<0.05$ was considered significant. 


\section{Conclusions}

In the present study, the initial bioassay tests conducted on the $80 \%$ methanol and hydrodistilled leaf extracts of $R$. multifidus indicated the antimalarial potency of the plant. The hydrodistilled extract was proven to express the highest potency in inhibiting growth of this pathogenic protozoan parasite. Further phytochemical analysis of the hydrodistilled extract resulted in the isolation of an $\alpha, \beta$-unsaturated dilactone characterized as anemonin. The investigation for antiprotozoal activity has demonstrated that anemonin exerts a strong potency for inhibiting the growth of the parasite, suggesting that it is responsible, in full or in part, for the antimalarial activity of the plant. To our knowledge, this study is the first to demonstrate the antimalarial activity of anemonin that has been isolated from the leaves of R. multifidus. Finally, the results produced in this study may serve as an additional reference in natural product research and may contribute to the further study of antiprotozoal drug discovery. The findings also support the use of the plant in the treatment of malaria in traditional medicine. The lack of toxicity and some specificity of the anti-infective effect, which is shown by a lack of growth inhibition of anemonin against mycobacteria, add to the safety and effectivity of the plant extract and its major active constituent. However, the present work has limitations in that the mode of action of the extract and anemonin against the parasite was not studied. Thus, further study to confirm the capability of anemonin to interact with the thiol group of cysteine by a Michael-type addition reaction needs to be carried out. Moreover, the GSH levels in the parasitized blood of mice should be measured in vitro in the presence and absence of anemonin to gain some insight into the mechanism(s) of action of the plant extract.

Supplementary Materials: The following are available online, TLC chromatograms, NMR, and HR-MS spectra of anemonin. Microscope slide photos of the negative control group (A), anemonin (B), and positive control group (C).

Author Contributions: Conceptualization, B.S., A.R., K.A. and P.I.; methodology, B.S., K.A., L.M. and A.R.; writing-original draft preparation, B.S.; writing—review and editing, K.A. and P.I.; supervision, K.A. and P.I.; project administration, K.A. and P.I.; funding acquisition, B.S., K.A. and P.I. All authors have read and agreed to the published version of the manuscript.

Funding: This study was supported by the School of Graduate Studies of Addis Ababa University research grant and was partially funded by the Deutsche Forschungsgemeinschaft (DFG, German Research Foundation)—432291016.

Institutional Review Board Statement: All the animal study procedures followed were reviewed and approved by the Institutional Review Board of the SoP, CHS, AAU. The mice were handled in accordance with the Guide for the Care and Use of Laboratory Animals [36].

Acknowledgments: One of the authors (B.S.) would like to acknowledge Addis Ababa University, School of Graduate Studies, for the research grant as well as Arba Minch University for sponsoring. The authors would like to express their gratitude to the Deutsche Forschungsgemeinschaft for partly funding the research work and Melaku Wondafrash of the National Herbarium, AAU, for authenticating the plant material. P.I. thanks the Federal Ministry of Education and Research (BMBF) (grant number 01DG17042B) for support in the context of the PhytoWood-Synergies project. We acknowledge the financial support of the Open Access Publication Fund of the Martin-LutherUniversity Halle-Wittenberg.

Conflicts of Interest: The authors declare no conflict of interest.

Sample Availability: Samples of the compound are available from the authors.

\section{References}

1. World Health Organization. World malaria report 2020: 20 years of global progress and challenges. In World Malaria Report 2020: 20 Years of Global Progress and Challenges; World Health Organization: Geneva, Switzerland, 2020.

2. Afrane, Y.A.; Zhou, G.; Githeko, A.K.; Yan, G. Clinical malaria case definition and malaria attributable fraction in the highlands of western Kenya. Malar. J. 2014, 13, 405. [CrossRef] [PubMed] 
3. Hay, S.I.; Guerra, C.A.; Tatem, A.J.; Noor, A.M.; Snow, R.W. The global distribution and population at risk of malaria: Past, present, and future. Lancet Infect. 2004, 4, 327-336. [CrossRef]

4. Girum, T.; Shumbej, T.; Shewangizaw, M. Burden of malaria in Ethiopia, 2000-2016: Findings from the Global Health Estimates 2016. Trop. Dis. Travel Med. Vaccines 2019, 5, 11. [CrossRef]

5. Kendie, F.A.; W/kiros, T.H.; Nibret Semegn, E.; Ferede, M.W. Prevalence of malaria among adults in Ethiopia: A systematic review and meta-analysis. J. Trop. Med. 2021, 2021, 8863002. [CrossRef] [PubMed]

6. Abebe, W. An overview of Ethiopian traditional medicinal plants used for cancer treatment. Eur. J. Med. Plants 2016, 14, 1-16. [CrossRef]

7. Kasali, F.M.; Mahano, A.O.; Kadima, N.J.; Mpiana, P.T.; Ngbolua, K.N.; Tshibangu, T.S.D. Ethnopharmacological survey of medicinal plants used against malaria in Butembo City (DR Congo). J. Adv. Bot. Zool. 2014, 1, 1-11.

8. Aschale, Y.; Wubetu, M.; Reta, H. Ethnobotany of medicinal plants used to treat leishmaniasis in Ethiopia: A systematic review. J. Tradit. Med. Clin. Naturopat. 2018, 7, 2-7. [CrossRef]

9. Birhan, Y.S.; Kitaw, S.L.; Alemayehu, Y.A.; Mengesha, N.M. Ethnobotanical study of medicinal plants used to treat human diseases in Enarj Enawga district, East Gojjam zone, Amhara region, Ethiopia. SM J. Med. Plant Stud. 2017, 1, 1-9. [CrossRef]

10. Wolde-Mariam, M.; Limenih, Y.; Umer, S. Ethnobotanical study on traditional medicinal plants in Dega Damot woreda, Amhara Region, North Ethiopia. Int. J. Res. Pharm. Chem. 2015, 5, 258-273.

11. De Wet, H.; Ngubane, S.C. Traditional herbal remedies used by women in a rural community in northern Maputaland (South Africa) for the treatment of gynecology and obstetrics complaints. S. Afr. J. Bot. 2014, 94, 129-139. [CrossRef]

12. Naidoo, D.; van Vuuren, S.F.; van Zyl, R.L.; De Wet, H. Plants traditionally used individually and in combination to treat sexually transmitted infections in northern Maputaland, South Africa: Antimicrobial activity and cytotoxicity. J. Ethnopharmacol. 2013, 149, 656-667. [CrossRef]

13. Southwell, I.A.; Tucker, D.J. Protoanemonin in Australian Clematis. Phytochemistry 1993, 33, 1099-1102. [CrossRef]

14. Clarkson, C.; Maharaj, V.J.; Crouch, N.R.; Grace, O.M.; Pillay, P.; Matsabisa, M.G.; Bhagwandin, N.; Smith, P.J.; Folb, P.I. In vitro antiplasmodial activity of medicinal plants native to or naturalised in South Africa. J. Ethnopharmacol. 2004, 92, 177-191. [CrossRef]

15. Basir, R.; Rahiman, S.F.; Hasballah, K.; Chong, W.C.; Talib, H.; Yam, M.F.; Jabbarzare, M.; Tie, T.H.; Othman, F.; Moklas, M.A.M.; et al. Plasmodium berghei ANKA infection in ICR mice as a model of cerebral malaria. Iran. J. Parasitol. 2012, 7, 62-66.

16. Krettli, A.U.; Adebayo, J.O.; Krettli, L.G. Testing of natural products and synthetic molecules aiming at new antimalarials. Curr. Drug Targets 2009, 10, 261-270. [CrossRef] [PubMed]

17. Ali, I.; Khatoon, S.; Amber, F.; Abbas, Q.; Ismail, M.; Engel, N.; Ahmad, V.U. Isolation of anemonin from Pulsatilla wallichiana and its biological activities. J. Chem. Soc. Pak. 2019, 41, 325.

18. Asahina, Y.; Fujita, A. Synthesis and constitution of anemonin. J. Pharm. Soc. Jpn. 1920, 455, 1-4.

19. Nono, R.N.; Nguelefack-Mbuyo, E.P.; Nzowa, L.K.; Ponou, B.K.; Teponno, R.B.; Nguelefack, T.B.; Barboni, L.; Tapondjou, L.A.; Park, H.J. Antioxidant C-glycosylflavones of Drymaria cordata (Linn.) Willd. Arch. Pharmacal Res. 2016, 39, 43-50. [CrossRef]

20. Saidi, R.; Ghrab, F.; Kallel, R.; El Feki, A.; Boudawara, T.; Chesné, C.; Ammar, E.; Jarraya, R.M. Tunisian Clematis flammula essential oil enhances wound healing: GC-MS analysis, biochemical and histological assessment. J. Oleo Sci. 2018, 67, 1483-1499. [CrossRef]

21. Gertsch, J. How scientific is the science in ethnopharmacology? Historical perspectives and epistemological problems. J. Ethnopharmacol. 2009, 122, 177-183. [CrossRef]

22. Becker, K.; Rahlfs, S.; Nickel, C.; Schirmer, R.H. Glutathione-functions and metabolism in the malarial parasite Plasmodium falciparum. J. Biol. Chem. 2003, 384, 551-566. [CrossRef]

23. Zhao, R.; Lind, J.; Merényi, G.; Eriksen, T.E. Significance of the intramolecular transformation of glutathione thiyl radicals to $\alpha$-aminoalkyl radicals. Thermochemical and biological implications. J. Chem. Soc. Perkin Trans. 1997, 2, 569-574. [CrossRef]

24. Zhang, Y.A.; Hempelmann, E.; Schirmer, R.H. Glutathione reductase inhibitors as potential antimalarial drugs: Effects of nitrosoureas on Plasmodium falciparum in vitro. Biochem. Pharmacol. 1988, 37, 855-860.

25. Davioud-Charvet, E.; Becker, K.; Landry, V.; Gromer, S.; Logé, C.; Sergheraert, C. Synthesis of 5,5'-dithiobis (2-nitrobenzamides) as alternative substrates for trypanothione reductase and thioredoxin reductase: A microtiter colorimetric assay for inhibitor screening. Anal. Biochem. 1999, 268, 1-8. [CrossRef] [PubMed]

26. Färber, P.M.; Arscott, L.D.; Williams, C.H., Jr.; Becker, K.; Schirmer, R.H. Recombinant Plasmodium falciparum glutathione reductase is inhibited by the antimalarial dye methylene blue. FEBS Lett. 1998, 422, 311-314. [CrossRef]

27. Vennerstrom, J.L.; Makler, M.T.; Angerhofer, C.K.; Williams, J.A. Antimalarial dyes revisited: Xanthenes, azines, oxazines, and thiazines. Antimicrob. Agents Chemother. 1995, 39, 2671-2677. [CrossRef]

28. Meister, A.; Anderson, M.E. Glutathione. Annu. Rev. Biochem. 1983, 52, 711-760. [CrossRef] [PubMed]

29. Townsend, D.M.; Tew, K.D.; Tapiero, H. The importance of glutathione in human disease. Biomed. Pharmacother. 2003, 57, 145-155. [CrossRef]

30. Wang, S.T.; Chen, H.W.; Sheen, L.Y.; Lii, C.K. Methionine and cysteine affect glutathione level, glutathione-related enzyme activities and the expression of glutathione S-transferase isozymes in rat hepatocytes. J. Nutr. 1997, 127, 2135-2141. [CrossRef]

31. Mares, D. Antimicrobial activity of protoanemonin, a lactone from ranunculaceous plants. Mycopathologia 1987, 98, 133-140. [CrossRef] 
32. Hall, I.H.; Lee, K.H.; Mar, E.C.; Starnes, C.O.; Waddell, T.G. Antitumor agents. 21. A proposed mechanism for inhibition of cancer growth by tenulin and helenalin and related cyclopentenones. J. Med. Chem. 1977, 20, 333-337. [CrossRef]

33. Cavallito, C.J.; Haskell, T.H. The mechanism of action of antibiotics. The reaction of unsaturated lactones with cysteine and related compounds. J. Am. Chem. Soc. 1945, 67, 1991-1994. [CrossRef]

34. Canepa, G.E.; Bouvier, L.A.; Miranda, M.R.; Uttaro, A.D.; Pereira, C.A. Characterization of Trypanosoma cruzi L-cysteine transport mechanisms and their adaptive regulation. FEMS Microbiol. Lett. 2009, 292, 27-32. [CrossRef] [PubMed]

35. Richter, A.; Strauch, A.; Chao, J.; Ko, M.; Av-Gay, Y. Screening of preselected libraries targeting Mycobacterium abscessus for drug discovery. Antimicrob. Agents Chemother. 2018, 62, e00828-18. [CrossRef] [PubMed]

36. Institute for Laboratory Animal Research (ILAR). Guide for the Care and Use of Laboratory Animals; The National Academy Press: Washington, DC, USA, 1996.

37. Organization for Economic Co-operation and Development (OECD). Guideline for the Testing of Chemicals: Acute Oral Toxicity-Upand-Down Procedure; Organization for Economic Co-operation and Development (OECD): Paris, France, 2008.

38. Tang, Y.; Dong, Y.; Wittlin, S.; Charman, S.A.; Chollet, J.; Chiu, F.C.; Charman, W.N.; Matile, H.; Urwyler, H.; Dorn, A.; et al. Weak base dispiro-1,2,4-trioxolanes: Potent antimalarial ozonides. Bioorg. Med. Chem. Lett. 2007, 17, 1260-1265. [CrossRef] [PubMed]

39. Fidock, D.A.; Rosenthal, P.J.; Croft, S.L.; Brun, R.; Nwaka, S. Antimalarial drug discovery: Efficacy models for compound screening. Nat. Rev. Drug Discov. 2004, 3, 509-520. [CrossRef]

40. Hilou, A.; Nacoulma, O.G.; Guiguemde, T.R. In vivo antimalarial activities of extracts from Amaranthus spinosus L. and Boerhaavia erecta L. in mice. J. Ethnopharmacol. 2006, 103, 236-240. [CrossRef] [PubMed]

41. Peters, W. Antimalarial drugs and their actions. Postgrad. Med. J. 1973, 49, 573-583. [CrossRef] [PubMed]

42. Waako, P.J.; Gumede, B.; Smith, P.; Folb, P.I. The in vitro and in vivo antimalarial activity of Cardiospermum halicacabum L. and Momordica foetida Schumch. Et Thonn. J. Ethnopharmacol. 2005, 99, 137-143. [CrossRef]

43. Mergia, E.; Shibeshi, W.; Terefe, G.; Teklehaymanot, T. Antitrypanosomal activity of Verbascum sinaiticum Benth. (Scrophulariaceae) against Trypanosoma congolense isolates. BMC Complement. Altern. Med. 2016, 16, 362. [CrossRef]

44. Tamiru, W.; Engidawork, E.; Asres, K. Evaluation of the effects of 80\% methanolic leaf extract of Caylusea abyssinica (fresen.) fisch. \& Mey. on glucose handling in normal, glucose loaded and diabetic rodents. BMC Complement. Altern. Med. 2012, $12,151$.

45. Misganaw, D.; Engidawork, E.; Nedi, T. Evaluation of the antimalarial activity of crude extract and solvent fractions of the leaves of Olea europaea (Oleaceae) in mice. BMC Complement. Altern. Med. 2019, 19, 171. [CrossRef]

46. Ancelin, M.L.; Calas, M.; Bonhoure, A.; Herbute, S.; Vial, H.J. In vivo antimalarial activities of mono- and bis-quaternary ammonium salts interfering with Plasmodium phospholipid metabolism. Antimicrob. Agents Chemother. 2003, 47, $2598-2605$. [CrossRef]

47. Fentahun, S.; Makonnen, E.; Awas, T.; Giday, M. In vivo antimalarial activity of crude extracts and solvent fractions of leaves of Strychnos mitis in Plasmodium berghei infected mice. BMC Complement. Altern. Med. 2017, 17, 13. [CrossRef]

48. Ryley, J.F.; Peters, W. The antimalarial activity of some quinolone esters. Ann. Trop. Med. Parasitol. 1970, 64, 209-222. [CrossRef]

49. Mulaw, T.; Wubetu, M.; Dessie, B.; Demeke, G.; Molla, Y. Evaluation of antimalarial activity of the 80\% methanolic stem bark extract of Combretum molle against Plasmodium berghei in mice. J. Evid.-Based Integr. Med. 2019, 24, 2515690X19890866. [CrossRef] [PubMed]

50. Nureye, D.; Assefa, S.; Nedi, T.; Engidawork, E. In vivo antimalarial activity of the $80 \%$ methanolic root bark extract and solvent fractions of Gardenia ternifolia Schumach. and Thonn. (Rubiaceae) against Plasmodium berghei. Evid.-Based Complement. Altern. Med. 2018, 2018, 9217835. [CrossRef]

51. Bantie, L.; Assefa, S.; Teklehaimanot, T.; Engidawork, E. In vivo antimalarial activity of the crude leaf extract and solvent fractions of Croton macrostachyus Hocsht. (Euphorbiaceae) against Plasmodium berghei in mice. BMC Complement. Altern. Med. 2014, 14, 79. [CrossRef] [PubMed]

52. Mekuria, A.; Geta, M.; Birru, E.; Gelayee, A. Antimalarial activity of seed extracts of Schinus molle against Plasmodium berghei in mice. J. Evid.-Based Integr. Med. 2021, 26, 2515690X20984287. [CrossRef] [PubMed]

53. Peters, W. Drug resistance in Plasmodium berghei Vincke and Lips, 1948. III. Multiple drug resistance. Exp. Parasitol. 1965, 17, 97-102. [CrossRef]

54. Peters, W.; Robinson, B.L. The chemotherapy of rodent malaria. Studies on pyronaridine and other Mannich base antimalarials. Ann. Trop. Med. Parasitol. 1992, 86, 455-465. [CrossRef] [PubMed] 